\title{
EFFECTS OF NUTRIENT SOLUTION SALINITY ON THE PHYSIOLOGICAL PERFORMANCE OF MELON CULTIVATED IN COCONUT FIBER ${ }^{1}$
}

\author{
PATRÍCIA LÍGIA DANTAS DE MORAIS ${ }^{2}$, NILDO DA SILVA DIAS ${ }^{2}$, ANDRÉ MOREIRA DE OLIVEIRA ${ }^{2}$, \\ OSVALDO NOGUEIRA DE SOUSA NETO², JOSÉ DARCIO ABRANTES SARMENTO ${ }^{2 *}$, MARIA ISIDÓRIA SILVA \\ GONZAGA $^{3}$
}

\begin{abstract}
Brackish waters represent great potential for profitable agricultural production; however, productive usage depends on the adoption of proper cultural practices as well as a culture tolerant of salinity, which can require some restrictions related to soil and crop production. Given the lack of information pertaining to hydroponic melon culture, the objective of this study was to investigate physiological changes promoted by the use of brackish water in the preparation of the nutrient solution for melon (Cucumis melo L., cv. AF 015) growth in coconut fiber substrate under greenhouse conditions in Mossoró-RN, a semiarid region of Brazil. The experimental design was completely randomized, with 12 treatments arranged in a $4 \times 3$ factorial scheme, with 4 salt concentration levels $\left(1.1\right.$ - control, 2.5, 4.0 and $\left.5.5 \mathrm{dS} \mathrm{m}^{-1}\right)$ and 3 exposition times (vegetative growth: 10-30 days after transplanting, DAT; flowering: 31 to 50 DAT; and fruiting and ripening: 51-70 DAT, which are the assessment phases of physiological maturation). Increasing salt concentrations in the nutrient solution reduced photosynthetic efficiency, stomatal conductance and transpiration, but increased the intercellular $\mathrm{CO}_{2}$ concentration in melon plants. A salt concentration in the low to intermediate range $\left(2.5 \mathrm{dS} \mathrm{m}^{-1}\right)$ resulted in the best water use efficiency by melon crops.
\end{abstract}

Keywords: Cucumis melo L.. Electric conductivity. Photosynthesis.

\section{EFEITOS DA SALINIDADE DA SOLUÇÃO NUTRITIVA SOBRE O DESEMPENHO FISIOLÓGICO DO MELÃO CULTIVADO EM FIBRA DE COCO}

RESUMO - A água salobra pode representar um grande potencial para a produção agrícola rentável, com base na adoção de práticas culturais adequadas e tolerância das culturas à salinidade, contrapondo aos problemas produtivos e de solo que normalmente ocasionam. Devido à escassez de informações sobre o cultivo hidropônico de melão, o presente estudo teve o objetivo de investigar as alterações fisiológicas provocadas pelo uso de água salobra no preparo da solução nutritiva para o cultivo de melão (Cucumis melo L., cv. AF 015) em ambiente protegido e em substrato de fibra de coco, em Mossoró-RN, região semiárido do Brasil. $\mathrm{O}$ delineamento experimental utilizado foi o inteiramente casualizado, com 12 tratamentos arranjados em esquema fatorial $4 \times 3$, sendo 4 níveis de concentração de sais $\left(1,1 \mathrm{dS} \mathrm{m}^{-1}\right.$ - controle, 2,5, 4,0 e 5,5 dS m $\left.\mathrm{dS}^{-1}\right)$ e fases de desenvolvimento (vegetativo: 10-30 dias após o transplantio, DAT; floração: 31-50 DAT e frutificação: 51-70 DAT, que representam as fases de avaliação da maturação fisiológica) com três repetições. $\mathrm{O}$ aumento da concentração de sal da solução nutritiva reduziu a eficiência da fotossíntese, da condutância estomática e da transpiração e aumentou a concentração intracelular de $\mathrm{CO}_{2} \mathrm{em}$ plantas de melão. A melhor eficiência do uso da água pela cultura do melão cultivada em fibra de coco foi alcançada na solução nutritiva com concentração de $2.5 \mathrm{dS} \mathrm{m}^{-1}$.

Palavras-chave: Cucumis melo L.. Condutividade elétrica. Fotossíntese.

\footnotetext{
"Corresponding author

${ }^{1}$ Received for publication in 02/24/2017; accepted in 10/23/2017.

Paper extracted from the dissertation of master of the third author.

${ }^{2}$ Center for Agrarian Sciences, Department of Agronomic and Forest Sciences, Universidade Federal Rural do Semi-Árido, Mossoró, RN, Brazil; plmorais@ufersa.edu.br _ ORCID: 0000-0001-9317-1164, nildo@ufersa.edu.br - ORCID: 0000-0002-1276-5444, andremoreira@ufersa.edu.br - ORCID: 0000-0003-4083-1821, osvaldo.neto@ufersa.edu.br - ORCID: 0000-0002-6256-4333, darcioabrantes@yahoo.com.br - ORCID: 0000-0002-7130-7718.

${ }^{3}$ AgronomyDepartment, Universidade Federal de Sergipe, São Cristóvão, SE, Brazil; mariaisisilva@gmail.com - ORCID: 0000-0002-7884 $-6386$.
} 


\section{INTRODUCTION}

In the fruit-producing region of Rio Grande do Norte, a semiarid region of Brazil, some of the water used for irrigation comes from deep artesian wells. Although it is a source of good quality water, high pumping costs make it economically prohibitive for agricultural use (SOUSA et al., 2009; MEDEIROS et al., 2014). Alternatively, irrigated water can be pumped at low costs from shallow wells in the Jandaíra limestone sediment, located on the north shore of the Rio Grande do Norte State and on the northeast of the Ceará State (VASCONCELOS; TEIXEIRA; ALVES NETO, 2010); however, it is considered brackish water and possesses a high salt concentration. The lower cost of pumping encourages the use of brackish water in this region, which can lead to degradation of vast areas of soil through salinization (MEDEIROS et al., 2017).

This problem could be reduced by mixing high and low quality water, which would increase the amount of water available to the crops. Dilution of brackish water reduces total salt concentration and allows irrigation of larger areas. However, the best dilution ratio must be determined in order to achieve better crop production and minimize environmental disturbance. Besides avoiding deleterious effects of high salinity on the plants and soil, such a management strategy could save fresh water and increase the availability of other water resources for agricultural use. Therefore, research on the rational use of these brackish waters becomes essential, as their uncontrolled use may increase the risk of soil salinization (DIAS et al., 2007; DIAS et al., 2011; TURHAN et al., 2014), especially in regions of high evapotranspiration rates and low rainfall (MEDEIROS et al., 2017).

Hydroponic systems can be advantageous when using brackish water due to the absence of matric potential, which allows increased crop tolerance to high salinity (MEDEIROS et al., 2007; SOARES et al., 2007). Moreover, hydroponic systems alleviate the problem of soil contamination and, as an extra benefit, provide people an alternative source of water for agricultural production in semiarid regions.

Salinity affects plant performance directly through water stress, toxicity caused by ions and nutritional imbalance (MEDEIROS et al., 2008; ARAGÃO et al., 2009; TERCEIRO NETO et al., 2014; PEREIRA et al., 2016), as well as indirectly by mediating inter-specific competition (ACOSTA-MOTOS et al., 2017). Thus, as a response to the damage caused by excess salt concentrations, many plants increase their tolerance mechanisms through the exclusion and/or compartmentalization of salt. Melon crops are considered moderately tolerant to salt stress, as was observed by Medeiros et al. (2008). In their study,
Electric Conductivity (EC) values up to $3.31 \mathrm{dS} \mathrm{m}^{-1}$ did not affect melon yield. Conversely, a reduction in productivity is commonly observed when the culture is irrigated with water containing a high salt concentration (ARAGÃO et al., 2009; HUANG et al., 2011; MEDEIROS et al., 2011). However, little is known about physiological changes within melon crops grown under high salt concentration in hydroponic systems. Therefore, this work aimed to evaluate physiological changes among melon plants grown under greenhouse conditions in a nutrient solution prepared with brackish water and using coconut fiber as a substrate.

\section{MATERIAL AND METHODS}

Experiments were conducted in a greenhouse at the Department of Environmental and Technological Sciences of the Federal Rural University of Semiarid (UFERSA), located in Mossoró (latitude $5^{\circ} 11^{\prime} \mathrm{S}$, longitude $37^{\circ} 20^{\prime} \mathrm{W}$ and altitude $18 \mathrm{~m})$. The study design was completely randomized, using a 4 × 3 factorial scheme, with 4 levels of salinity in the nutrient solution (1.1 - control, 2.5, 4.0 and $\left.5.5 \mathrm{dS} \mathrm{m}^{-1}\right)$ and 3 phenological stages of melon plants (10-30 days after plant transplanting - DAT), flowering (31-50 DAT) and fruiting and ripening (51-70 DAT), with 3 replicates each.

The melon seeds (Cucumis melo L., cv. AF 015) were planted in polystyrene trays containing 128 cells filled with coconut fiber substrate. Within 13 days of sprouting, seedlings were transplanted into $12 \mathrm{~L}$ plastic bags containing a $2 \mathrm{~cm}$ gravel layer at the bottom, covered with nylon mesh and filled with $3.5 \mathrm{~kg}$ of coconut fiber (Golden Mix ${ }^{\circledR}$ ). The experimental units were arranged in six rows with $1.00 \mathrm{~m} \times 0.50 \mathrm{~m}$ between plants. Fence posts were installed at the end of each plant row in order to guide plant growth.

The nutrient solution was prepared with water of different salinity levels: tap water $\left(\mathrm{EC}=0.52 \mathrm{dS} \mathrm{m}^{-1}\right)$, well water $\left(\mathrm{EC}=3.7 \mathrm{dS} \mathrm{m}^{-1}\right)$, mixed water and well water with $\mathrm{NaCl}$ added. After water preparation, basic nutrient solution fertilizers were added as recommended by Santos and Minami (2002). Briefly, $805 \mathrm{~g}$ of calcium nitrate, $334 \mathrm{~g}$ of potassium nitrate, $175 \mathrm{~g}$ of ammonium phosphate, $252 \mathrm{~g}$ of magnesium sulfate and $10 \mathrm{~g}$ of Quelatec were added to each $100 \mathrm{~L}$ of water.

Plant physiological parameters were evaluated during the flowering phase (31-50 DAT), between 9:00 and 10:00 am. Photosynthetic rate (A) ( $\left.\mu \mathrm{mol} \mathrm{CO}_{2} \mathrm{~m}^{-2} \mathrm{~s}^{-1}\right)$, stomatal conductance (gs) (mmol $\left.\mathrm{H}_{2} \mathrm{O} \quad \mathrm{m}^{-2} \mathrm{~s}^{-1}\right)$, transpiration (E) $\left(\mathrm{mmol} \mathrm{H}_{2} \mathrm{O} \quad \mathrm{m}^{-2} \mathrm{~s}^{-1}\right)$ and intercellular $\mathrm{CO}_{2}$ concentrations $(\mathrm{Ci})\left(\mu \mathrm{mol} \mathrm{CO} \mathrm{Col}^{-1}\right)$ were measured on healthy leaves between the $9^{\circ}$ and $13^{\circ}$ node using an infrared gas analyzer (IRGA, LI-COR 6400) with 
a constant light source of $1.200 \mu \mathrm{mol} \mathrm{m} \mathrm{m}^{-2} \mathrm{~s}^{-1}$ photons. Water use efficiency (WUE) was quantified by dividing photosynthesis/transpiration rate.

All results are expressed as an average of three replicates. Treatment effects were determined by analysis of variance according to SISVAR. Regression analyses were performed to investigate the relationship between salt concentration levels and plant physiological parameters.

\section{RESULTS AND DISCUSSION}

The photosynthetic rates of melon plants were reduced $\left(\mathrm{R}^{2}=0.98\right)$ with increasing electrical conductivity of the nutrient solution. The reduction was $14 \%$ between the lowest $\left(1.1 \mathrm{dS} \mathrm{m}^{-1}\right)$ and highest $\left(5.5 \mathrm{dS} \mathrm{m}^{-1}\right)$ salinity levels of the nutrient solution (Figure 1A). However, intracellular $\mathrm{CO}_{2}$ concentrations increased $\left(\mathrm{R}^{2}=0.94\right)$ with increasing nutrient solution salinity levels (Figure $1 \mathrm{~B}$ ), which is generally ascribed to salt-tolerant species. Reductions were also observed in stomatal conductance $\left(\mathrm{R}^{2}=0.88\right)$ and transpiration rates (Figures $1 \mathrm{C}$ and $\mathrm{D}$ ).
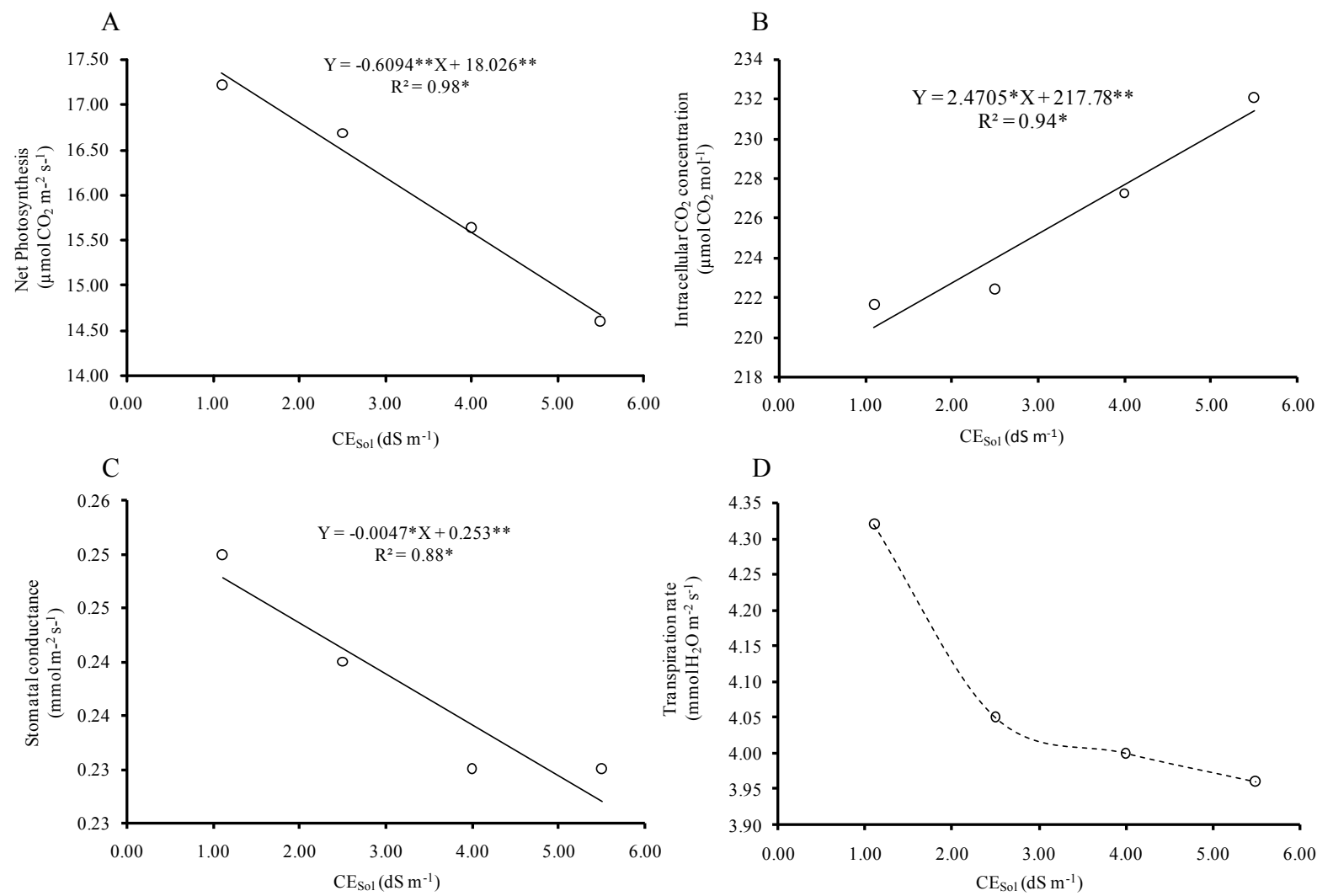

Figure 1. Photosynthetic liquid (A), intracellular $\mathrm{CO}_{2}$ concentration (B), stomatal conductance (C) and transpiration rate (D) in melon plants (Cucumis melo L., cv. AF 015) growing in nutrient solution with different levels of salt concentration.

Photosynthesis, the physicochemical process by which plants, algae and photosynthetic bacteria use light energy to drive the synthesis of organic compounds, involves three phases: first, atmospheric $\mathrm{CO}_{2}$ enters the substomatal chamber by diffusion; second, light energy is absorbed through a photochemical reaction where water molecules are broken down to release oxygen and electrons. Both oxygen and electrons will be used to activate the production of ATP (Adenosine triphosphate) and NADPH (nicotinamide adenine dinucleotide phosphate); in the third phase, $\mathrm{CO}_{2}$ is synthesized into organic molecules through the activity of the enzyme RuBisCo (D-ribulose 1,5-bisphosphate carboxylase/oxygenase) (TAIZ;
ZEIGER, 2010). In the present study, there were no observed changes in the first phase of the process. However, although carbon was detected in the substomatic chamber and available for the photosynthetic process, it was not synthesized during the carboxylation phase. This is probably due to plant stress caused by salinity levels higher than $2.5 \mathrm{dS} \mathrm{m}^{-1}$ (Figure 1A), and suggests restricted function during the following phases of photosynthesis. For instance, based on the equation shown in Figure 1A, the highest photosynthetic rate (17.28 $\left.\mu \mathrm{mol} \mathrm{CO}_{2} \mathrm{~m}^{-2} \mathrm{~s}^{-1}\right)$ was estimated for the lowest level of salinity $\left(1.1 \mathrm{dS} \mathrm{m}^{-1}\right)$. Conversely, the lowest photosynthetic rate was observed for the highest level of salinity $\left(5.5 \mathrm{dS} \mathrm{m}^{-1}\right)$. Huang et al. 
(2011) found similar results when melon plants were grown with and without water stress, they observed photosynthetic rates of $15.7 \mu \mathrm{mol} \quad \mathrm{CO}_{2} \mathrm{~m}^{-2} \mathrm{~s}^{-1}$ (highest value) under normal growing conditions and 9.6 $\mu \mathrm{mol} \mathrm{CO}_{2} \mathrm{~m}^{-2} \mathrm{~s}^{-1}$ in plants growing under water stress conditions. A linear reduction in the photosynthetic rate was also observed by Bezerra et al. (2005) after growing young dwarf cashew plants with increasing levels of salinity in the irrigation water. Several plant species were also affected by the photosynthetic rate due salt stress (NEGRÃO et al., 2017). Pereira et al. (2004) observed decreasing photosynthetic rates of $11.8,24.1$ and $49.4 \%$, respectively, in tomato plants grown in 50, 100 or $150 \mathrm{mM} \mathrm{NaCl}$ solutions.

As opposed to the reduced photosynthetic rate, higher values of intercellular $\mathrm{CO}_{2}$, (222 $\mu \mathrm{mol} \mathrm{CO}_{2} \mathrm{~mol}^{-1}$ to $233 \mu \mathrm{mol} \mathrm{CO} \mathrm{mol}^{-1}$ ) were observed with increasing salinity levels (Figure 1B). According to Sivakumar, Sharmila and Saradhi (2000), who also observed an accumulation of $\mathrm{CO}_{2}$ in the intercellular spaces of many plant species, this happens when $\mathrm{CO}_{2}$ does not enter the carboxylation-dependent photosynthetic phase. In melon plants, Mavrogianopoulos, Spanakis and Tsikalas (1999) observed intercellular $\mathrm{CO}_{2}$ concentrations of approximately $300 \mu \mathrm{mol} \mathrm{CO} \mathrm{Col}^{-1}$ when plants were grown in a solution enriched with $400 \mu \mathrm{mol} \mathrm{mol}{ }^{-1}$ of $\mathrm{CO}_{2}$. They also confirmed that high salt levels in growing media for melon plants lead to a reduction in photosynthetic rates, stomatal conductance and internal $\mathrm{CO}_{2}$ concentration.

The findings of the present study, demonstrate that salinity levels correlate to photosynthetic rates and intracellular $\mathrm{CO}_{2}$ concentrations of melon plants, suggesting the presence of a specific type of tolerance mechanism in these plants. The photosynthetic rate was still reasonably high when the level of salinity was around $4.00 \mathrm{dS} \mathrm{m}^{-1}$ (Figure 1A). Therefore, the melon plant might either exclude the toxic $\mathrm{Na}^{+}$ions from the shoots or compartmentalize it into its specific parts, avoiding severe growth reductions (MUNNS; TESTER, 2008). Furthermore, reduced photosynthetic rate was related to the total salt concentration and ionic composition of the nutrient solution. High salt concentrations increase the osmotic potential, reducing water availability for plants. Low water potential leads to osmotic stress and can irreversibly affect the enzymes and photosynthetic ion transport system in the plasma membrane (PAPAGEORGIOU et al., 1998). Storey and Walker (1998) reported that a reduction in photosynthesis due to salt stress can result from reduced cell turgor pressure, Calvin cycle inhibition and $\mathrm{K}^{+}$or $\mathrm{Cl}^{-}$deficiency. This is because electron transport in the chloroplasts is salt indifferent.

Transpiration rates of melon plants were reduced with increasing salt levels in the nutrient solution and values ranged from $4.32 \mathrm{mmol} \mathrm{H}_{2} \mathrm{O} \mathrm{m}^{-2} \mathrm{~s}^{-1}$ to $3.97 \mathrm{mmol} \mathrm{H}_{2} \mathrm{O} \mathrm{m}^{-2} \mathrm{~s}^{-1}$ for salt levels of 1.0 and $5.5 \mathrm{dS} \mathrm{m}^{-1}$, respectively (Figure 1D). A similar value $\left(4.2 \mathrm{mmol} \mathrm{H}_{2} \mathrm{O} \mathrm{m}^{-2} \mathrm{~s}^{-1}\right)$ was reported by Huang et al. (2011) when they cultivated melons under water stress in China. These results are also in agreement with those found for stomatal conductance, which decreased with increasing salt concentrations (ANDRADE JÚNIOR et al., 2011; FERNANDES et al., 2010). The reduction in this variable is a reflection of stomatal behavior in response to water vapor loss. According to Vieira Júnior et al. (2008), 95\% of the total water absorbed by the plant is used in the transpiration process to maintain thermal equilibrium.

The relationship between photosynthesis and transpiration rate is related to water use efficiency and indicates the capacity of the plant to assimilate $\mathrm{CO}_{2}$ despite water vapor loss. In this study, an increase in water use efficiency was observed for salt concentrations from 1.1 to $2.5 \mathrm{dS} \mathrm{m}^{-1}$ in the irrigation water. However, with salt concentrations of 4 and $5.5 \mathrm{dS} \mathrm{m}^{-1}$ there was a reduction in water use efficiency, indicating that the $\mathrm{CO}_{2}$ fixation/water loss ratio was favored by intermediate salinity levels $\left(2.5 \mathrm{dS} \mathrm{m}^{-1}\right)$ (Figure 2).

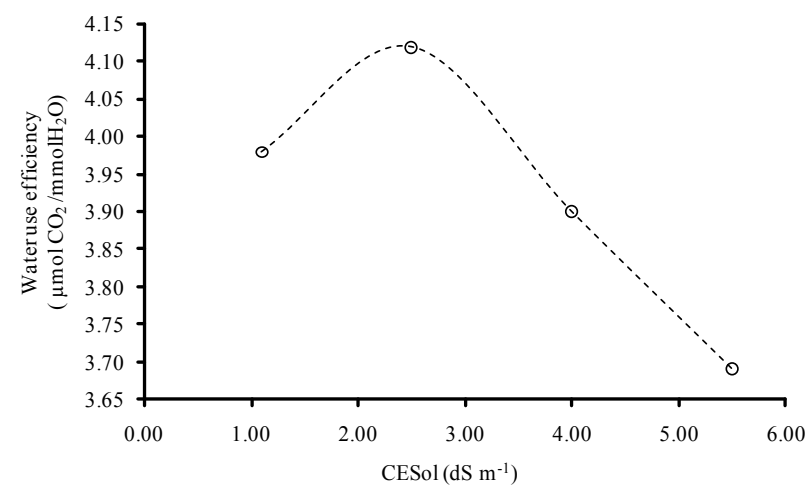

Figure 2. Water use efficiency as a function of salt concentration in nutrient solutionin melon plants (Cucumis melo L., cv. AF 015). 
Huang et al. (2011) studied saline stress in melon plants, and observed a photosynthetic water use efficiency value of $1.78 \mu \mathrm{mol} \mathrm{CO}_{2} \mathrm{mmol} \mathrm{H}_{2} \mathrm{O}$ for plants growing under water stress and a value of $3.27 \mu \mathrm{mol} \mathrm{CO}_{2}$ mmol $\mathrm{H}_{2} \mathrm{O}$ for plants growing in control treatment. In our study, melon plants benefited from a slightly higher salinity level $(2.5 \mathrm{dS}$ $\mathrm{m}^{-1}$ ), which caused an increase of approximately $4 \%$ in water use efficiency (Figure 2); suggesting that plants submitted to small levels of stress may be able to maximize water use through mechanisms to increase $\mathrm{CO}_{2}$ assimilation. This is a desirable trait in plants that are tolerant to salinity. Our results differ from those of Huang et al. (2011), they they reported a linear relationship between increased water stress and reductions in photosynthetic rate, stomatal conductance, intercellular $\mathrm{CO}_{2}$ concentration and transpiration rate.

\section{CONCLUSIONS}

Increasing salinity levels in the nutrient solution reduced photosynthetic efficiency, stomatal conductance, transpiration rates and increased intercellular $\mathrm{CO}_{2}$ concentrations in melon plants. Water use efficiency in melon plants was highest for a salt concentration of $2.5 \mathrm{dS} \mathrm{m} \mathrm{m}^{-1}$ in the nutrient solution. The per capita ratio and loss of water in the melon crop environment is more efficient under salt concentrations of the nutrient solution ranging from low to intermediate levels.

\section{ACKNOWLEDGMENTS}

We would like to extend our gratitude to Conselho Nacional de Desenvolvimento Científico e Tecnológico (CNPq), Fundação de Apoio à Pesquisa do Rio Grande do Norte (FAPERN), Coordenação de Aperfeiçoamento de Pessoal de Nível Superior (CAPES), Brazil, for the scholarships and financial support.

\section{REFERENCES}

ACOSTA-MOTOS, J. R. et al. Plant Responses to Salt Stress: Adaptive Mechanisms. Agronomy, Basel, v. 7, n. 1, p. 18, 2017.

ANDRADE JÚNIOR, W. P. et al. Efeito do nitrato de potássio na redução do estresse salino no meloeiro. Revista Caatinga, Mossoró, v. 24, n. 3, p. 110-119, 2011.

ARAGÃO, C. A. et al. Avaliação de cultivares de melão sob condições de estresse salino. Revista Caatinga, Mossoró, v. 22, n. 2, p. 161-169, 2009.
BEZERRA, M. A. et al. Crescimento e fotossíntese de plantas jovens de cajueiro anão precoce sob estresse salino. Revista Brasileira de Engenharia Agrícola e Ambiental, Campina Grande, v. 9, Sup., p. 90-94, 2005.

DIAS, N. S. et al. Salinização do solo por aplicação de fertilizantes em ambiente protegido. Irriga, Botucatu, v. 12, n. 1, p. 135-143, 2007.

DIAS, N. S. et al. Uso de rejeito da dessalinização na solução nutritiva da alface, cultivada em fibra de coco. Revista Ceres, Viçosa, v. 58, n. 5, p. 632-637, 2011 .

FERNANDES, O. B. et al. Efeito do nitrato de cálcio na redução do estresse salino no meloeiro. Revista Caatinga, Mossoró, v. 23, n. 3, p. 93-103, 2010.

HUANG, Z. et al. Physiological and photosynthetic responses of melon (Cucumis melo L.) seedlings to three Glomus species under water deficit. Plant and Soil, Crawley, v. 339, n. 1-2, p. 391-399, 2011.

MAVROGIANOPOULOS, G. N.; SPANAKIS, J.; TSIKALAS, P. Effect of carbon dioxide enrichment and salinity on photosynthesis and yield in melon. Scientia Horticulturae, Amsterdam, v. 79, n. 1, p. 51-63, 1999.

MEDEIROS, D. C. et al. Produção e qualidade de melão cantaloupe cultivado com água de diferentes níveis de salinidade. Revista Caatinga, Mossoró, v. 24, n. 1, p. 92-98, 2011.

MEDEIROS, J. F. et al. Crescimento do meloeiro cultivado sob diferentes níveis de salinidade, com e sem cobertura do solo. Revista Brasileira de Engenharia Agrícola e Ambiental, Campina Grande, v. 11, n. 3, p. 248-255, 2007.

MEDEIROS, J. F. et al. Crescimento e acúmulo de $\mathrm{N}, \mathrm{P}$ e $\mathrm{K}$ pelo meloeiro irrigado com água salina. Horticultura Brasileira, Vitória da Conquista, v. 26, n. 4, p. 452-457, 2008.

MEDEIROS, J. F. et al. Management strategies of saline water on morphometric characteristics of melon cultivars. Engenharia Agrícola, Jaboticabal, v. 34, n. 4, p. 649-659, 2014.

MEDEIROS, J. F. et al. Salinidade e pH de um argissolo irrigado com água salina sob estratégias de manejo. Revista Brasileira de Agricultura Irrigada, Fortaleza, v. 11, n. 3, p. 1407, 2017.

MUNNS, R.; TESTER, M. Mechanisms of salinity tolerance. Annual Review of Plant Biology, Palo Alto, v. 59, s/n., p. 651-681, 2008. 
NEGRÃO, S. et al. Evaluating physiological responses of plants to salinity stress. Annals of Botany, Bethesda, v. 119, n. 1, p. 1-11, 2017.

PAPAGEORGIOU, G. C. et al. A method to probe the cytoplasmic osmolality and osmotic water and solute fluxes across the cell membrane of cyanobacteria with chlorophyll a fluorescence: experiments with Synechococcus sp. PCC7942. Physiologia Plantarum, Lund, v. 103, n. 2, p. 215 224, 1998.

PEREIRA, C. C. M. S. et al. Componentes bioquímicos e crescimento de meloeiro sob estresse hídrico associado à Meloidogyne incognita e Bacillus spp. Revista Brasileira de Agricultura Irrigada, Fortaleza, v. 10, n. 4, p. 739-749, 2016.

PEREIRA, F. H. F. et al. Trocas gasosas em plantas de tomateiro submetidas a condições salinas. In: CONGRESSO BRASILEIRO DE OLERICULTURA, 44., 2004, Campo Grande. Anais... Campo Grande: SOB, 2004. p. 452.

SANTOS, R. N. C.; MINAMI, K. Cultivo hidropônico do meloeiro. 1. ed. Piracicaba, SP: DIBD, 2002. 38 p.

SIVAKUMAR, P.; SHARMILA, P.; SARADHI, P. Pardha. Proline alleviates salt-stress-induced enhancement in ribulose-1, 5-bisphosphate oxygenase activity. Biochemical and Biophysical Research Communications, Cambridge, v. 279, n. 2, p. 512-515, 2000.

SOARES, T. M. et al. Produção de alface utilizando águas salinas em sistema hidropônico. Irriga, Botucatu, v. 12, n. 2, p. 235-248, 2007.

SOUSA, R. B. C. et al. Variação sazonal das águas subterrâneas utilizadas para irrigação na microrregião de Tibau, RN. Revista Caatinga, Mossoró, v. 22, n. 4, p. 206-213, 2009.

STOREY, R.; WALKER, R. R. Citrus and salinity. Scientia Horticulturae, Amsterdam, v. 78, n. 1, p. 39-81, 1998.

TAIZ, L.; ZEIGER, E. Plant Physiology. 5. ed. New York: Sinauer Associates, 2010. 782 p.

TERCEIRO NETO, C. P. C. et al. Crescimento do meloeiro 'pele de sapo' irrigado com água salobra com diferentes estratégias de manejo. Revista Caatinga, Mossoró, v. 27, n. 2, p. 87-100, 2014.

TURHAN, A. et al. Effect of different concentrations of diluted seawater on yield and quality of lettuce. Chile an Journal of Agricultural
Research, Chillán, v. 74, n. 1, p. 111-116, 2014. VASCONCELOS, S. M. S.; TEIXEIRA, Z. A.; ALVES NETO, J. Caracterização do Aquifero Jandaíra, porção situada no Estado do Ceará, Brasil. Revista de Geologia, Fortaleza, v. 23, n. 1, p. 50-60, 2010 .

VIEIRA JÚNIOR, P. A. et al. Relações entre o potencial e a temperatura da folha de plantas de milho e sorgo submetidas a estresse hídrico. Acta Scientiarum. Agronomy, Maringá, v. 29, n. 4, p. $555-561,2008$. 